Acta vet. scand. $1977,18,323-334$.

From the Department of Physiology, Endocrinology and Bloodgrouping, Royal Veterinary and Agricultural University, Copenhagen,

Denmark.

\title{
GLUTATHIONE PEROXIDASE ACTIVITY IN PORCINE BLOOD*
}

\author{
By \\ P. Fogd Jørgensen, J. Hyldgaard-Jensen and J. Moustgaard
}

\begin{abstract}
JØRGENSEN, P. FOGD, J. HYLDGAARD-JENSEN and J. MOUSTGAARD: Glutathione peroxidase activity in porcine blood. Acta vet. scand. 1977, 18, 323-334. - Determination of the seleno-enzyme glutathione peroxidase (GSH-Px) in blood from Danish Landrace pigs was done using a quantitative, spectrophotometric method and a simple "spot test". A close correlation between the net reaction rate measured spectrophotometrically $(\Delta \mathrm{A} / \mathrm{min}$.) and time for defluorescence (minutes) was obtained $\left(\mathrm{r}^{2}=0.72-0.77, \mathrm{P}<0.0005\right)$. From these results the factors used for a conversion of defluorescence time to $\mathrm{u} / \mathrm{g}$ hemoglobin were evaluated. The results further showed that the "spot test" can be used as a screening method for detection of subnormal GSH-Px levels in pigs.

While red cell GSH-Px seems independent of the sex, an elevation of both plasma and red cell GSH-Px was found with increasing age of pigs. The normal range of red cell GSH-Px activity was wide, contrasting the small variations observed in the individual pig. Some evidence that porcine red cell GSH-Px is under genetical control was found and discussed in relation to the possible use of GSH-Px as an indicator of the pig's selenium status.
\end{abstract}

pigs; glutathione peroxidase; spectrophotometric determination; spot test; erythrocytes; plasma.

Determination of an animal's selenium requirement and status was until recently depending on time consuming methods and highly specialized laboratory equipment. The discovery that selenium is an integral part of the enzyme glutathione peroxidase (GSH-Px, E.C.1.11.1.9) and that selenium through this enzyme exerts protection against peroxidative damage like vitamin $\mathbf{E}$ (Rotruck et al. 1973, Tappel 1974) has, however, contributed

*) This work, which is part of the IAEA/FAO international joint project on methods for detecting mineral imbalances in animal, was supported by the Danish Agricultural and Veterinary Research Council. 
considerably not only to a better understanding of the synergistic effect of these two nutritive elements but also to the development of a sensitive index of the selenium status. Thus in chicken (Omaye \& Tappel 1974) and the rat (Hafeman et al. 1974) the blood plasma GSH-Px activity is highly correlated with selenium intake. Likewise a direct relationship between blood selenium concentration and the GSH-Px activity has been demonstrated in ruminants (Thompson et al.1976) and chickens (Noguchi et al. 1973). Analysis of this enzyme in blood may therefore provide a valuable index to monitor abnormal levels of enzyme activity related to improper selenium supplementation.

Selenium responsive diseases in pigs seem more important than hitherto believed (Trapp et al. 1970, Berschneider 1972), particularly in regions where the soil is seriously lacking in this element, hence there is need for sufficiently sensitive, simple and specific methods for its detection in this species.

This study comprises a comparison between a simple "spot test" and the spectrophotometric assay of GSH-Px in porcine blood and also gives some preliminary data on normal blood levels in pigs.

\section{MATERIALS AND METHODS}

Blood samples were taken from the v. cava cran. from 56 Danish Landrace pigs representing 14 litters. Each litter consisted of two female and two castrated male pigs ranging in age from 12 to 14 weeks. From four 6-month old pigs blood samples were taken on four consecutive days in order to determine the day to day variation in GSH-Px activity. A material of 40 pigs ranging in age from two to 200 days was used to investigate influence of age on the red cell and plasma GSH-Px activity.

The heparinized blood was centrifuged and the erythrocytes washed twice in saline. Erythrocytes were then kept at $-20^{\circ} \mathrm{C}$ until analysed within the next two-three days. Upon thawing hemolysates were diluted with nine volumes of a solution containing potassium cyanide $1.6 \mathrm{mmol} / \mathrm{l}$, potassium ferricyanide $1.2 \mathrm{mmol} / 1$ and sodium hydrogen carbonate $23.8 \mathrm{mmol} / \mathrm{l}$.

The GSH-Px activity was determined by two different methods:

(a) Spectrophotometric determination of GSH-Px was carried out according to Günzler et al. (1974). The method was modified so as to give optimal conditions for the porcine enzyme. 
Final concentration of reagents was tert. butylhydroperoxide $1.67 \mathrm{mmol} / \mathrm{l}$, glutathione (reduced) $9.89 \mathrm{mmol} / \mathrm{l}$, nicotineamideadenine-dinucleotide phosphate (NADPH) $0.489 \mathrm{mmol} / \mathrm{l}$, glutathione reductase $7.9 \mathrm{u} / \mathrm{ml}$, phosphate $0.139 \mathrm{~mol} / \mathrm{l}, \mathrm{pH} 7.2$. GSH-Px activity is expressed as $\mathrm{u}\left(\mu \mathrm{moles} / \mathrm{min}\right.$. at $\left.25^{\circ} \mathrm{C}\right)$ per $\mathrm{g}$ of hemoglobin $(\mathrm{Hb})$. Hemoglobin was determined by the method of van Kampen \& Zijlstra (1961).

(b) The "spot test" used was essentially the same as described by Board \& Peter (1976) for sheep blood. The method is based on the fluorescent properties of NADPH, whose disappearance as a result of the GSH-Px activity can be examined under ultraviolet light. Following start of the reaction by adding $50 \mu \mathrm{l}$ hemolysate or $50 \mu \mathrm{l}$ plasma to $200 \mu \mathrm{l}$ of the complete reaction mixture, a drop of the mixture is spotted on non fluorescing filter paper (Whatman No. 1); further spots are made at 1-5 min. intervals. The spots are then examined under ultra violet light in the dark (Fig. 1). Time of defluorescence in minutes reflects the enzyme activity in tested samples.

\section{RESULTS}

In normal pigs the original fluorescence of NADPH disappears within $7-8 \mathrm{~min}$. (Fig. 1). The mean time of defluorescence in red cells from normal pigs at this particular age was found to be $2.5 \pm 1.5 \mathrm{~min}$. If the normal range is stated as $\bar{x} \pm 2 \mathrm{~s}$, a range of $0-5.5 \mathrm{~min}$. is obtained.

\begin{tabular}{|c|c|c|c|c|c|c|c|c|c|c|c|c|}
\hline \multirow{2}{*}{ Sample } & \multicolumn{11}{|c|}{ MINUTES } & \multirow[b]{2}{*}{30} \\
\hline & 0 & 1 & 2 & 3 & 4 & 5 & 6 & .7 & 10 & 15 & 20 & \\
\hline \multicolumn{13}{|l|}{$\begin{array}{l}\text { Red Cell } \\
\text { (high) }\end{array}$} \\
\hline \multicolumn{13}{|l|}{$\begin{array}{l}\text { Red Cell } \\
\text { (low) }\end{array}$} \\
\hline \multicolumn{13}{|c|}{$\begin{array}{c}\text { Red Cell } \\
\text { ( subnormal) }\end{array}$} \\
\hline \multicolumn{13}{|l|}{ Plasma } \\
\hline $\begin{array}{l}\text { Reaction } \\
\text { mixture } \\
\text { only }\end{array}$ & & & & & & & & & & & & \\
\hline
\end{tabular}

Fig u re 1. Results of the "spot test" for GSH-Px activity in hemolysates and plasma from normal pigs. Fluorescent spots are dark. 


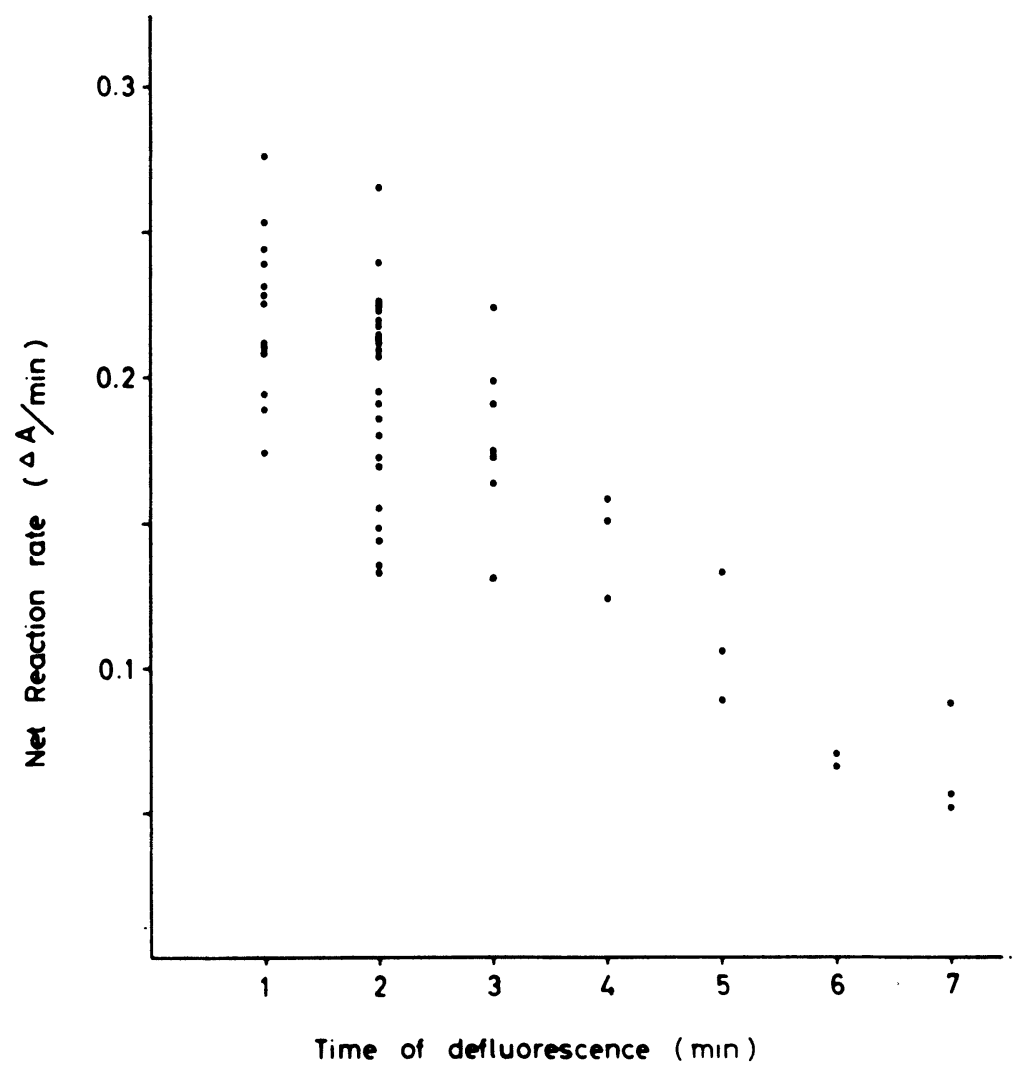

Fig u r e 2. Relationship between the time of defluorescence and the spectrophotometric net reaction rate in red cell GSHPx from 56 pigs.

The correlation between the "spot test" and the quantitative spectrophotometric determination of GSH-Px in hemolysates from 56 normal pigs is shown in Fig. 2. The correlation coefficients calculated on basis of the gross and net (gross minus blank) reaction of the spectrophotometric method were -0.87 and $-0.85(\mathrm{P}<0.0005)$, respectively.

The association between the net reaction rate determined spectrophotometrically ( $\Delta \mathrm{A} / \mathrm{min}$.) and time of defluorescence $(t)$ in red cells from two litters with high and two litters with low GSH-Px activity is expressed by equations stated below. Equations (1) and (2) refer to erythrocyte samples taken at an interval of four-five weeks from the same animals. 


$$
\begin{gathered}
(\Delta \mathrm{A} / \mathrm{min} .)=(0.173 \pm 0.028) \times 1 / \mathrm{t}+(0.065 \pm 0.016) \\
\mathbf{r}^{2}=0.722, \mathrm{P}<0.0005 \\
(\Delta \mathrm{A} / \mathrm{min} .)=(0.190 \pm 0.027) \times 1 / \mathrm{t}+(0.036 \pm 0.012) \\
\mathbf{r}^{2}=0.770, \mathrm{P}<0.0005
\end{gathered}
$$

From these equations the factors used for conversion of defluorescence time to $\mathrm{u} / \mathrm{g} \mathrm{Hb}$ have been derived (Table 1 ). To obtain $\mathrm{u} / \mathrm{g} \mathrm{Hb}$ from a given defluorescence time the corresponding $F$ value is divided by $A_{540}$, which is the absorbance at $540 \mathrm{~nm}$ of a mixture of $100 \mu \mathrm{l}$ diluted hemolysate and $5 \mathrm{ml}$ Drabkin solution.

Table 1. Conversion factors (F) for the calculation of GSH-Px activity $(\mathrm{u} / \mathrm{g} \mathrm{Hb})$ from time of defluorescence.

\begin{tabular}{cccc}
\hline \multirow{2}{*}{$\begin{array}{c}\text { Time of defluorescence } \\
\text { (minutes) }\end{array}$} & \multicolumn{3}{c}{ F } \\
\cline { 2 - 4 } & mean & \multicolumn{2}{c}{$95 \%$ confidence limits } \\
\cline { 2 - 4 } & 46.4 & 38.6 & lower \\
\hline 1 & 28.2 & 24.6 & 54.2 \\
2 & 22.6 & 18.6 & 31.8 \\
3 & 19.2 & 15.2 & 25.6 \\
4 & 17.4 & 13.0 & 23.0 \\
5 & 16.2 & 11.6 & 21.6 \\
6 & & & 20.6 \\
\hline
\end{tabular}

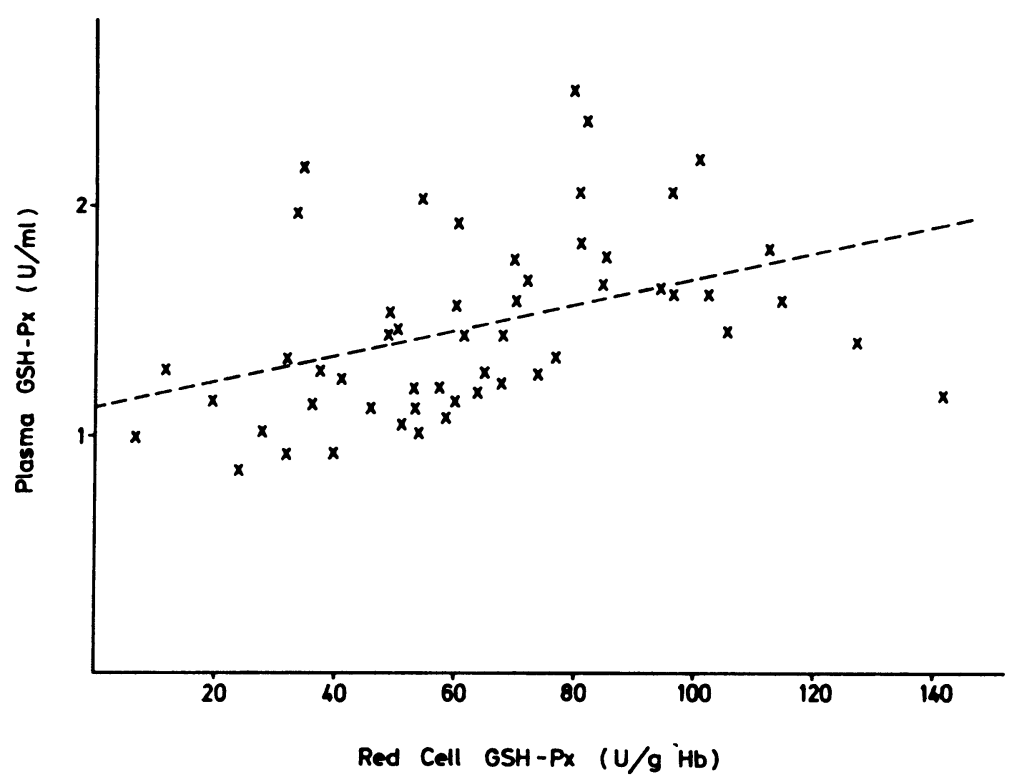

Figure 3. A comparison between the GSH-Px activity in plasma and red cells from 56 pigs. 
A comparison between plasma and erythrocyte GSH-Px activity is shown in Fig. 3. Using a reference blood hemoglobin value of $10 \mathrm{~g} / 100 \mathrm{ml}$ and a plasma/blood volume ratio of 0.60 the average contribution of plasma and erythrocytes to total blood GSH-Px activity amounts to $14.2 \%$ and $85.8 \%(\mathrm{~s}=7.2)$, respectively. For plasma the range was found to be as wide as 4 $47 \%$. Although the distribution of GSH-Px between plasma and erythrocytes varies, a certain correlation does seem to exist $(\mathrm{r}=0.411, \mathrm{P}<0.01)$.

T a b l e 2. Day to day variation of red cell GSH-Px activity $(\mathrm{u} / \mathrm{g} \mathrm{Hb})$ in four pigs.

\begin{tabular}{lrrrrrr}
\hline Pig no. & $25 / 10$ & $26 / 10$ & $27 / 10$ & $28 / 10$ & Mean & C. V.* $(\%)^{*}$ \\
\hline 531 & 105.0 & 114.0 & 149.0 & 102.0 & 117.4 & 18 \\
533 & 71.0 & 77.0 & 78.0 & 78.0 & 75.4 & 4 \\
534 & 124.0 & 100.0 & 97.0 & 85.0 & 101.4 & 5 \\
535 & 79.0 & 65.0 & 81.0 & 74.0 & 74.4 & 9 \\
\hline
\end{tabular}

* C. $\mathrm{V}=$ coefficients of variation.

The day to day variation in red cell GSH-Px activity appears from Table 2. In individual pigs red cell enzyme activity is practically constant, thus the variation between pigs is significantly higher than the variation from day to day in the single pig $(\mathrm{F}=8.79, \mathrm{P}<0.01)$. As shown in Table 3 red cell and in particular pasma GSH-Px are elevated with increasing age of pigs. The increase seems most marked within a month after birth.

The material consisting of 14 litters is particularly suitable for investigating a possible genetic influence on the GSH-Px activity, as all pigs were kept in the same environment and given the

T a b l e 3. Age dependent changes in erythrocyte and plasma GSHPx activity.

\begin{tabular}{rcrccc}
\hline $\begin{array}{l}\text { Age } \\
\text { (days) }\end{array}$ & $\begin{array}{c}\text { Number } \\
\text { of animals }\end{array}$ & $\begin{array}{c}\text { Erythro- } \\
\text { cytes } \\
\text { (u/g Hb) }\end{array}$ & $\begin{array}{c}\text { \% of } \\
\text { initial } \\
\text { activity }\end{array}$ & $\begin{array}{c}\text { Plasma } \\
\text { (u/l plasma) }\end{array}$ & $\begin{array}{c}\text { \% of } \\
\text { initial } \\
\text { activity }\end{array}$ \\
\hline 2 & 4 & $66 \pm 12$ & & $482 \pm 83$ & \\
34 & 11 & $87 \pm 23$ & 130 & $1316 \pm 397$ & 273 \\
80 & 14 & $80 \pm 25$ & 121 & $1685 \pm 355$ & 349 \\
118 & 5 & $102 \pm 25$ & 155 & $1796 \pm 475$ & 372 \\
195 & 6 & $96 \pm 30$ & 145 & $2387 \pm 900$ & 494 \\
\hline
\end{tabular}


T a bl e 4. GSH-Px activity in erythrocytes (u/g $\mathrm{Hb})$ from 56 pigs (14 groups, four litter mates in each group). Means and coefficients of variation (C. V.) for each group are indicated. The figures reported in brackets refer to a second sampling done one month later.

\begin{tabular}{crrrr}
\hline Group no. & \multicolumn{2}{c}{$\begin{array}{c}\text { Mean activity } \\
\text { (u/g Hb) }\end{array}$} & \multicolumn{2}{c}{$\begin{array}{c}\text { c. v. } \\
(\%)\end{array}$} \\
\hline 912 & 122.0 & $(124.6)$ & 13 & $(6)$ \\
916 & 97.0 & $(109.6)$ & 14 & $(4)$ \\
908 & 90.0 & $(85.6)$ & 11 & $(7)$ \\
910 & 76.4 & $(103.8)$ & $38(15)$ \\
911 & 67.6 & $(82.4)$ & 7 & $(19)$ \\
909 & 62.2 & $(84.0)$ & $18(22)$ \\
913 & 61.4 & $(82.0)$ & $32(10)$ \\
915 & 53.4 & $(94.0)$ & 9 & $(13)$ \\
917 & 51.8 & $(100.0)$ & 5 \\
903 & 50.2 & $(69.2)$ & $28(32)$ \\
904 & 49.4 & $(35.8)$ & $39(43)$ \\
914 & 48.2 & $(75.6)$ & $24(17)$ \\
907 & 45.6 & $(42.6)$ & $41(27)$ \\
902 & 17.4 & $(33.4)$ & $62(12)$ \\
\hline
\end{tabular}

same diet. As it appears from Table 4, which shows the mean values and coefficients of variation for each litter, it is clear that the variation between litters is significantly higher than the variation within the single litter $(F=11.53, P<0.0005)$. In the present material the litter effect could thus explain about $80 \%$ of the total variation found in red cell GSH-Px. The reproducibility of the red cell GSH-Px activity was tested by collecting two blood samples at an interval of one month from 56 pigs. Although the second set of values were somewhat elevated the reproducibility between the two set of values was high $(r=0.705$, $\mathrm{P}<0.0005$ ).

The sex has no apparent influence on the red cell GSH-Px activity (females: $66 \pm 28 \mathrm{u} / \mathrm{g} \mathrm{Hb}$; males: $60 \pm 28 \mathrm{u} / \mathrm{g} \mathrm{Hb}$ ). Using the material as a whole the mean erythrocyte GSH-Px activity was $62 \pm 28 \mathrm{u} / \mathrm{g} \mathrm{Hb}$ with an overall range of $6.6-142.2$ $\mathrm{u} / \mathrm{g} \mathrm{Hb}$.

\section{DISCUSSION}

The identification of more and more vitamin and trace element-enzyme associations forms the basis of a new methodology by which deficiencies may be detected with a sensitivity and spe- 
cificity hitherto not obtainable by current methods. The recent discovery that GSH-Px is a seleno-enzyme, has widened considerably the possibilities not only for the elucidation of the biochemical role of this trace element but also for the detection of selenium deficiency states. This possibility is already underlined by findings which demonstrate a close correlation between tissue and red cell GSH-Px activity and selenium intake in chicken (Omaye \& Tappel 1974) and rats (Hafeman et al. 1974), just as it appears that the blood selenium and GSH-Px content is closely correlated in various species including cattle and sheep (Allen et al. 1975, Thompson et al. 1976). However, the latter-mentioned authors did not find similar close correlation between the selenium content and GSH-Px activity in porcine blood.

In contrast to this finding Ewan (1976) recently reported high correlations between the selenium content and GSH-Px activity in liver $(r=0.86)$, kidney $(r=0.90)$ and spleen $(r=$ 0.78) in both selenium deficient and supplemented pigs. Furthermore in pigs that were either selenium deficient or given intramuscular injections of selenium $(0.05 \mathrm{mg}$ sodium selenite/kg body weight) a low and high serum GSH-Px were found, respectively.

Before attempting to assess the value of blood enzyme analyses as indices of trace element deficiencies it is important to realize that properties of an enzyme may vary with the species with origin of the tissue, rate of synthesis and removal as well as the influence of physiological factors such as animal age, sex, genetics and nutritional state. In the present study on porcine blood GSH-Px some of these factors have been elucidated.

The results show that determination of GSH-Px in blood can be done either by using the quantitative, spectrophotometric method or by a simple "spot test". The latter method seems very suitable to identify pigs with a subnormal GSH-Px activity. As these levels are of particular interest in connection with selenium deficiency, since defluorescence in normal pigs occurs within 6 -7 min., it is possible to simplify the method further by using a preincubation period of $5 \mathrm{~min}$. before the residual fluorescence is tested.

Whether determination of GSH-Px activity in red cells, plasma or whole blood should be preferred as a measure of selenium status is not yet clear. Thompson et al. reported negligible traces of enzyme activity in pig plasma, which is in con- 
trast to the relatively high GSH-Px activity found in pig plasma in the present study. Furthermore the enzyme activity in plasma was not particularly well related to the activity in red cells, therefore whole blood GSH-Px activity does not necessarily correspond to that of red cells. Results obtained in chicks (Omaye $\&$ Tappel) indicate that plasma GSH-Px activity responds more rapidly to changes in selenium intake than the activity in red cells, which was related to the rather long life span of the cells. It deserves mentioning, however, that while GSH-Px located in erythrocytes is selenium dependent, several other tissues also contain a selenium independent form of the enzyme (Lawrence $\&$ Burk 1977); part of the GSH-Px in plasma might originate from such tissues.

In contrast to the wide range of normal GSH-Px activity, individual levels are subjected to much less variation. Normal ranges as derived statistically may therefore result in misinterpretation of clinical data, and one should be cautious in relying on a single estimation.

The influence of various physiological factors on the blood GSH-Px level should not be overlooked. Thus it is clear that normal adult ranges are not applicable to young pigs (Table 3). Likewise the possible genetic influence on the red cell GSH-Px activity as found in the present study is another interfering factor. The fact that about $80 \%$ of the total variation in red cell GSH-Px could be explained by a litter effect both at the age of 12-14 weeks and one month later does support the genetical control of the enzyme level. Further support is gained by the fact that all pigs investigated were fed the same diet supplemented with selenium as sodium selenite. Genetically controlled blood enzyme activities in pigs have earlier been reported for plasma arylesterase (Kubek et al. 1969) and erythrocyte adenosine deaminase (Widar et al. 1974). A low or high red cell GSHPx activity level within the normal range is therefore not necessarily tantamount to a low or high selenium status as these levels at least partly are genetically based. Hence repeated determinations of GSH-Px combined with clinical observations - or better with a supplementation of animals with selenium are needed in order to evaluate the selenium status on this basis.

Assuming that the variations in red cell GSH-Px activity mainly are genetically based and that selenium as part of the enzyme molecule amounts to a considerable part of the cell's 
total selenium content, one might expect that cellular selenium is subject to similar control. This may be part of the explanation why Thompson et al. found a poor correlation $(\mathrm{r}=0.27, \mathrm{P}>0.1)$ between blood selenium and GSH-Px in pigs. In this context the high correlations found by Ewan between tissue selenium content and GSH-Px activity in pigs seem to support such theory. Experimentally induced selenium deficiency as well as repletion of pigs with supplementary selenium is, however, needed for a further elucidation of that important question.

Selenium responsive diseases may be more widespread in pigs than hitherto recognized. Lesions to skeletal muscles and heart (Van Vleet et al. 1970), liver (Ewan \& Wastell 1970, Simesen \& Pedersen 1975) and the locomotor system (Berschneider 1972) appear to be the predominant types. As some of these conditions may also involve a vitamin $\mathbf{E}$ deficiency, analyses of GSH-Px might prove useful both from a diagnostic point of view but also as part of the efforts to establish optimal requirements of selenium in pigs under various environmental conditions.

\section{REFERENCES}

Allen, W. M., W. H. Parr, P. H. Anderson, Sylvia Berrett, R. Bradley \& D. S. P. Patterson: Selenium and the activity of glutathione peroxidase in bovine erythrocytes. Vet. Rec. 1975, 96, 360-361.

Berschneider, F.: Biochemische Untersuchungen zum Problem der Bewegungsanomalien des Fleischschweines. In Gesundheitliche Aspekte der Fleischschweinproduktion. (Biochemical investigations of anomalies of the locomotor system in pigs. In Health aspects of pig production). (ed. E. Wiesner), VEB Gustav Fischer Verlag, Jena 1972, p. 89-157.

Board, P. G. \& D. W. Peter: A simple test for glutathione peroxidase and selenium deficiency. Vet. Rec. 1976, 99, 144-145.

Ewan, R. C.: Effect of selenium on glutathione peroxidase. J. Anim. Sci. 1976, 42, 1352.

Ewan, R. C. \& M. E. Wastell: Effect of vitamin $\mathrm{E}$ and selenium on blood composition of the young pig. J. Anim. Sci. 1970, 31, 343 -352 .

Günzler, W. A., H. Kremers \& L. Flohé: An improved coupled test procedure for glutathione peroxidase (E.C.1.11.1.9) in blood. Z. klin. Chem. 1974, 10, 444-448.

Hafeman, D. G., R. A. Sunde \& W. G. Hoekstra: Effect of dietary selenium on erythrocyte and liver glutathione peroxidase in rats. J. Nutr. 1974, 104, 580-587. 
Kubek, A., M. Hesselholt \& P. B. Nielsen: Undersøgelser over plasmaarylesterasevariationer hos svin. (A study of plasma arylesterase variations in pig). Kgl. Vet.- og Landbohøjsk., Inst. Sterilitetsforskn., Årsberetn. 1969, 12, 9-29. København.

Lawrence, R. A. \& R. F. Burk: Species and tissue distribution of non selenium-dependent glutathione peroxidase activity. (Abstract) Fed. Prod. 1977, 36, 1095.

Noguchi, T., A. H. Cantor \& M. L. Scott: Mode of action of selenium and vitamin $E$ in prevention of exudative diathesis in chicks. J. Nutr. 1973, 103, 1502-1511.

Omaye, S. T.\& A. L. Tappel: Effect of dietary selenium on glutathione peroxidase in the chicks. J. Nutr. 1974, 104, 747-753.

Rotruck, J. T., A. L. Pope, H. E. Ganther, A. B. Swanson, D. G. Hafeman \& W. G. Hoekstra: Selenium: biochemical role as a component of glutathione peroxidase. Science 1973, 179, 588-590.

Simesen, M. G. \& K. B. Pedersen: Selenium determinations in Danish swine affected with hepatosis dietetica. Acta vet. scand. 1975, 16, 137-139.

Tappel, A. L.: Selenium-glutathione peroxidase and vitamin E. Amer. J. clin. Nutr. 1974, 27, 960-965.

Thompson, R. H., C. H. McMurray \& W. J. Blanchflower: The levels of selenium and glutathione peroxidase activity in blood of sheep, cows and pigs. Res. Vet. Sci. 1976, 20, 229-231.

Trapp, A. L., K. K. Keahey, D. L. Whitenack \& C. K. Whitehair: Vitamin E-selenium deficiency in swine: Differential diagnosis and nature of field problem. J. Amer. vet. med. Ass. 1970, 157, 289 300.

Van Kampen, E. J. \& W. G. Zijlstra: Standardization of hemoglobinometry. II. The hemoglobincyanide method. Clin. chim. Acta $1961,6,538-544$.

Van Vleet, J. F., W. Carlton \& H. J. Olander: Hepatosis dietetica and mulberry heart disease associated with selenium deficiency in Indiana swine. J. Amer. vet. med. Ass. 1970, 157, 1208-1219.

Widar, J., M. Ansay \& R. Hanset: Polymorphism of adenosine deaminase in the pig: allelic variation in erythrocytes. Anim. Blood Grps biochem. Genet. 1974, 5, 115-124.

\section{SAMMENDRAG \\ Glutathion peroxydase aktivitet $i$ svineblod.}

Blod fra normale Dansk Landrace grise er analyseret for selenoenzymet glutathion peroxydase (GSH-Px) dels med en kvantitativ, spektrofotometrisk metode dels med en simpel "spot test". Der fandtes god overensstemmelse mellem de to metoder (Fig. 2) udtrykt ved sammenhængen mellem nettoreaktionshastigheden målt spektrofotometrisk ( $\triangle \mathrm{A} / \mathrm{min}$.) og tiden $\mathrm{i}$ minutter for defluorescensen $\left(\mathrm{r}^{2}=\mathbf{0 , 7 2}\right.$ -0,77, P < 0,005). På grundlag heraf er omregningstallene beregnet, 
hvilket muligg $\varnothing \mathbf{r}$ en omsætning af defluorescenstiden til aktivitetsenheder ( $u / g$ hæmoglobin). Under disse betingelser synes ,spot testen" velegnet som screeningsmetode til udpegning af subnormale blod GSH-Px værdier hos svin.

Kønnet influerer tilsyneladende ikke på blodets GSH-Px, derimod fandtes en stigning $i$ såvel erytrocyters som plasmaets GSH-Px aktivitet $i$ perioden fra fødsel til 6-7 måneders alderen. Normalområdet for erytrocyt GSH-Px aktiviteten er bredt; til gengæld er aktiviteten hos den enkelte gris betydelig mindre variabel. Da der tillige fandtes en væsentlig større variation $i$ erytrocyt GSH-Px aktiviteten mellem kuld end indenfor kuld, tyder disse resultater på, at svineblodets GSH-Px indhold er under genetisk kontrol. Betydningen af dette forhold samt $\varnothing$ vrige fysiologiske faktorers indflydelse på blodets GSH-Px aktivitet er diskuteret $i$ relation til en mulig anvendelse af dette parameter $i$ vurderingen af svinets selenstatus.

(Received April 4, 1977).

Reprints may be requested from: The Department of Physiology, Endocrinology and Bloodgrouping, Royal Veterinary and Agricultural University, Bülowsvej 13, DK-1870 Copenhagen V, Denmark. 